\title{
Análise da Situação Financeira do Municipıo de São Bernardo do Campo
}

(Resposta a consulta)

\author{
A. Delorenzo Neto \\ (Professor da Escola de Sociologia e Poli- \\ tica de São Paulo)
}

\section{$\mathrm{P}$} ARA fazer-se uma análise da situação financeira do Município de São Bernardo do Campo, conforme nos foi sclicitado pelo Exmo. Sr. Prefeito Aldino PinotTi, era necessário preliminarmente um levantamento de documentos principais, a saber :

- Orçamento de 1956;

- Balanço comparativo da receita arrecadada com a receita orçada em 1955;

- Discriminação dos créditos especiais - pagcs e a pagar;

- Demonstração da dívida ativa;

- Demonstração dos restos a pagar;

- Quadro demonstrativo da dívida flutuante;

- Quadro demonstrativo da divida fundada;

- Discriminação dos saldos das dotações orçamentárias de 1956;

- Arrecadação até 31 de maio de 1956.

A documentação oferecida pela Prefeitura nos permite algumas considerações de ordem teórica e prática, de interêsse para a administração.

\section{1}

O exame do orçamento municipal de São Bernardo do Campo, para o exercício de 1956 , revela que o mesmo não obedece na sua sistemática ao Decreto-lei n. ${ }^{\circ}$ 2.416, de 17 de julho de 1940, fonte das respectivas normas e padrões em vigor. Neste particular convém recordar as diretrizes metodológicas que devem nortear a boa técnica orçamentária, a partir dos próprios textos constitucionais cujos principios se incorporaram às Leis de Organização Municipal. Assim, a Lei Orgânica dos Municípios do Estado de São Paulo, estabelece a disciplina da matéria num Capítulo especial intitulado "Do Orçamento e da Ccntabilização", que dispõe expressamente : 
"Art. 85. O orçamento será organizado com observância às regras da unidade e universalidade, englobando-se obrigatòriamente na receita tôdas as rendas e suprimentos de fundos e incluindo-se discriminadamente na despesa as dotações necessárias ao custeio de todos os serviços públiccs.

$\S 10^{\circ} \mathrm{O}$ orçamento não conterá dispositivos estranhos à receita prevista e à despesa fixada, salvo :

I - autorização para abertura de créditos suplementares e operações de crédito pcr antecipação da receita até o limite da respectiva verba orçamentária; tário.

II - aplicação de saldos cu medidas necessárias ao equilíbrio orçamen-

$\S 2 .^{\circ} \quad$ orçamento da despesa divide-se em duas partes: uma fixa, que não poderá ser alterada senão em virtude de lei anterior; outra variável, que obedecerá a rigorosa especificação".

"Art. 86. São vedados o estôrno de verbas, a concesssão de créditos ilimitados e a abertura, sem autorização legislativa de créditos de qualquer natureza".

Os dois artigos citados indicam com clareza a orientação geral que deve presidir à elaboraçãc orçamentária. Porém, o conhecimento da receita prevista e da despesa fixada, sob os diverscs aspectos que a padronização do Decreto-Lei 2.416 permite, é possibilitado pelos quadros sintéticos que devem acompanhar o orçamento. Estes quadros, exigidos expressamente pelo Artigo 2. ${ }^{\circ}$ das Normas, são os seguintes :

$\left.1^{\circ}\right)$ receita segundo a incidência;

2. ${ }^{\circ}$ distribuiçãc da despesa por "elementos" e órgãos;

$\left.3 .^{\circ}\right)$ distribuição da despesa por "elementos" em cada serviço;

$4^{\circ}$ ) despesa por serviço em cada órgão administrativo.

Além dêsse mínimo indispensável, ainda consta do item $4 .^{\circ}$ das Normas, a recomendação para que o orçamento seja acompanhado da relação das leis que modificaram ou criaram os tributos vigentes, bem como as leis referentes ao pessoal fixo e a outras despesas que dependem de autorização legislativa. Tanto as tabelas explicativas da despesa como as da legislação de receita e despesa são de grande utilidade prática e científica, pois esclarecem os diferentes aspectos da previsão das rendas e da aplicação das despesas públicas, e a sua respectiva natureza jurídica.

O orçamento vigente de São Bernardo do Campo não obedece à terminologia adotada pelas "Normas" aprovadas pelo Decreto-lei n. ${ }^{\circ} 2.416$, sobretudo em matéria de classificação da despesa e organização dos seus quadros explicativos, e sem nenhuma alusão às fontes legais determinadcras da receita e da despesa. Portanto, indicamos como importe subsídio propedêutico à repartição da Prefeitura, responsável pela elaboração da proposta orçamentária, o estudo do Orçamento do Município de Vitória (publicado em apêndice. ao nosso trabalho - "A Codificação Municipal de Vitória" - Vol. II dos "Textos de Direito e Administração Municipal" - DNSP. Rio de Janeiro, 1955), e ainda o excelente compêndio de Afonso AlMIRo, intitulado "Técnica 
Orçamentária", Editôra Guaíra Limitada, Curitiba s/d.. Êstes dois textos serão, certamente, úteis à formação do funcionário, facilitando-lhe melhor compreensão das finalidades do orçamento. E necessário também melhor relacionar o orçamentc com a política social do município, pondo-o realmente a serviço das necessidades das populações que tenham uma inegável implicação administrativa. Por isso mesmo o orçamento não deverá ser uma mera relação de recursos e de despesas, mas, ao contrário, o verdadeiro instrumento de um avançado planejamento administrativo, capaz de gerar utilidades e condições de civilização em tôda a área de atuação do govêrno do municípic.

Considerando ainda as exigências administrativas do Município de São Bernardo do Campo, em face de sua população que se aproxima de 100.000 habitantes - notamos que sua arrecadação atual está deficitária, pcis, dentro da área econômica em que se situa, a sua média de tributação deverá atingir a Cr $\$ 1.500,00$ "per capita". Em conseqüência, se o orçamento há de apresentar um cunho progressista, só o poderá alcançar se se aperfeiçoar técnicamente a legislação tributária relacionando-a com os fatôres econômiccs.

Para encarecer diante dos responsáveis pela administração de São Bernardo, a importância administrativa do Orçamento, vamos referir as palavras do eminente prof. MAURICE DUVERGER, na sua recente "Institutions Financières", ao apreciar em têrmos de finanças modernas o significado do Orçamento: "Les conceptions nouvelies des finances publiques ont apporté de profonds bouleversements à la notion de budget. Dans son principe, cependant, cette notion est en accord avec les finances modernes: l'idée de dresser un plan d'ensemble des activités de l'Etat, d'utiliser les moyens d'action etatiques, d'une façcn cohérente et coordonnée, est en soi très moderne. Le budget est la première manifestation d'un "planisme" avant la lettre".

Essas expressões revelam um conceito perfeitamente aplicável ao orçamento municipal, que traz em si mesmo uma destinação objetiva, isto é, a de ser instrumento adequado para uma administração planificada, cujos recursos repousem sôbre uma base uniforme e coerente. Do contrário, burlado o seu sentido programático, o orçamento passará a ser a dissimulação da indisciplina e da desorganização administrativa.

II

Passemos a interpretar os documentos financeiros que solicitamos à Prefeitura :

\section{A - Balanço comparativo da receita arrecadada com a receita orçada em 1955 .}

A receita do exercício foi orçada em $\mathrm{Cr} \$ 38.000 .000,00$, com uma arrecadação igual a Cr\$ 69.658.081,30, o que revela bom ritmo de expansão financeira. Mas, a observação da receita tributária nos Distritos acusa nos mesmos arrecadação "a menos", fato êsse que merece reexame da parte da Prefeitura do ponto de vista do aperfeiçoamento do aparêlho arrecadador.

(1) "in" Institutions Financières (Thémis), Presses Universitaires de France, Paris, p. 259,1956 . 
Ainda assim se observa certa desproporção entre as receitas os Impostos Predial e Territorial Urbano, sendo respectivamente de $\mathrm{Cr} \$ 4.000 .000,00$ e ... Cr\$ 8.200.000,00, quando ambas deverão ser muito mais elevadas, considerando as condições peculiares do desenvolvimento urbano, tendo em vista a comparação de dados estatísticos.

Igual apreciação será válida para os Impostos de Indústrias e Profissões, de Licença e de Jogos e Diversões, respectivamente orçadcs em Cr\$ ..... 5.250.000,00, Cr\$ 425.000,00 e Cr\$200.000,00.

A receita de taxas parece-nos muito incipiente merecendo melhor cuidado da parte da administraçäo. A única receita que se afigura razoável é da Taxa de Conservação de Estradas de Rodagem, orçada em Cr\$ 6.000.000,00. Estas reflexões nos levam à conclusão segura de que deve ser reformada a legislação tributária vigente, porquanto o Município de São Bernardo do Campo comporta arrecadação não inferior a Cr\$ 100.000.000,00 diante da conjuntura econômica em que se situa.

B - Discriminação dos créditos especiais em 31 de maio de 1956.

A demonstração efetuada pela Prefeitura acusa uma despesa extraordinária num total de Cr\$ 16.718.298,00, autorizada pelas Leis $\mathrm{n}^{\mathrm{os}}$. 427, 428, 442 e 445 . Dêsse total ainda é necessário pagar a importância de ....... Cr\$ 14.469.285,70. Parece-nos demasiado elevada essa quantia consignada em créditos especiais se atentarmos para o orçamento vigente, de ....... Cr\$ 55.500.000,00. E ainda cumpre notar que são despesas relativas a um semestre. Neste particular será relevante a cocperação da Câmara Municipal, no sentido de não serem autorizadas senão as despesas realmente indispensáveis, e de estrito interêsse da administração.

C - Demonstração da dívida ativa.

O quadro que nos demonstra a posição da dívida ativa, até 31 de maio de 1956, denuncia o domínio da Prefeitura nesse setcr. Pois, a dívida apresentando-se no início do exercicio, num total de $\mathrm{Cr} \$ 19.341 .056,90$ teve sua arrecadação efetuada em soma igual a $\mathrm{Cr} \$ 5.797 .883,70$, o que representa significativa percentagem.

$D$ - Demonstração dos restos a pagar.

A situação revelada pela posição dos Restos a pagar, em 31 de maio de 1956 indica a tendência para a sua rápida liquidação. O total de . . . . . . Cr\$ 1.846.787,50 (quando no início do exercício impcrtava em ....... Cr\$ 4.861.857,00) não representa um índice que possa perturbar a administração. Porém, será prudente tôda vigilância nesse aspecto financeiro, pois, a negligência neste particular poderá ser desastrosa para a execução orçamentária.

\section{E - Quadro demonstrativo da Dívida Fundada.}

A dívida fundada do Município, se restringe ao Empréstimo junto à Caixa Econômica Estadual, de Cr\$ 15.000.000,00 mas, cujas obrigações não se verificam consignadas no Orçamento. Essa divida fundada é perfeitamente admissível dentro do quadro das suas possibilidades crçamentárias. Mas, 
para que essa despesa não prejudique a normalidade financeira, é urgente que se estabeleça a sua respectiva consignação orçamentária a partir de 1957 .

F - Discriminação dos saldos das dotações orçamentárias de 1956.

Uma boa medida de ccntrôle da despesa pelo Prefeito Municipal, é, sem dúvida, a apreciação periódica do saldo das dotações orçamentárias, ao menos, mensalmente. O quadro de sua discriminação, em cinco meses de execução orçamentária, acusa um saldo sôbre o total de Cr\$ $55.500 .000,00$, de .... Cr\$ 41.298.706,60. Isto significa que não houve irreflexão na autorização dos gastos públicos, mas gradual e vigilante aplicação das dotações da despesa. Esta é orientação salutar que deverá ser adotada em proveito do equilíbrio financeiro, evitando que o executivo se desnorteie nos pedidos desordenados de créditos suplementares.

\section{G - Arrecadação até 31 de maio de 1956.}

A arrecadação efetuada pela Prefeitura até 31 de maio de 1956 num total de $\mathrm{CrS} 21.548 .795,40$, nos indica uma situação boa financeira para o exercício, pois, essa importância representa quas s cinqüenta por cento da receita orçada. Podemos assegurar, observada a posição das receitas principais de Impostcs e Taxas, que será apreciável o excesso de arrecadação, aproximadamente da ordem de $\mathrm{Cr} \$ 20.000 .000,00$.

\section{III}

Não nos foi possível obter a posição da dívida flutuante. Porém, a documentação apresentada é suficiente a nos permitir o conhecimento da situação financeira do Município. É necessário que em face da instabilidade dcs preços, seja considerado sempre o exame prévio das despesas, dando-se preferência às econômicamente reprodutivas, fazendo no que toca às obras públicas a eliminação das obras suntuárias ou adiáveis. Quanto acs servidores, não será conveniente exceder a atual percentagem de despesa.

Como a área urbana vive uma fase de intensa modificação de estrutura, é necessário que o orçamento consigne anualmente uma dotação especial para desapropriações nunca inferior a $\mathrm{CrS} 5.000 .000,00$, pelo menos enquanto forem necessárias as intervenções urgentes em matéria de saneamento e urbanismo. Ainda como recomendação final, a lembrança da adoção, como norma dogmática, do empenho prévio para tôdas as despesas municipais. Além de ser uma determinaçãc legal, expressa no Artigo 15 da Codificação aprovada pelo Decreto-lei n. ${ }^{\circ} 2.416$, de 17 de julho de 1940, é, pois, o empenho condição de validade para o pagamento da despesa. Em conseqüência, a realização de qualquer despesa sem o indispensável empenho, implica na respon. sabilidade do ordenador. É um instituto moralizador que visa frear os dispêndios públicos, constituindo um instrumento eficaz para a fiscalização administrativa.

A prática das recomendações aqui lembradas com apoio na doutrina e na legislação, aliada ao cuidado de aperfeiçoar técnicamente cs serviços de administração financeira pròpriamente dita - propiciarão, sem dúvida, à Prefeitura e ao Município de São Bernardo do Campo elementos seguros e decisivos para os encargos e exigências de sua recuperação e desenvolvimento. 